\title{
Pengaruh Dosis Mikoriza dan Pupuk Rock Posfat terhadap Pertumbuhan dan Hasil Tanaman Melon (Cucumis melo L.)
}

The Effect of Doses of Mychorryzae and Rock Phospate Fertilizer on the Growth and Yield of Melon Plants (Cucumis melo L.)

\author{
Muhammad Rizal', Nurhayati ${ }^{1}$, Nanda Mayani ${ }^{1}$ \\ Jurusan Agroteknologi, Fakultas Pertanian, Universitas Syiah Kuala
}

\begin{abstract}
Abstrak. Penelitian bertujuan untuk mengetahui pengaruh dosis mikoriza dan pupuk rock posfat yang tepat terhadap pertumbuhan dan hasil tanaman melon.Penelitian dilaksanakan di Kebun Percobaan 3 Fakultas Pertanian Universitas Syiah Kuala Banda Aceh pada Desember 2018 sampai Februari 2019. Penelitian menggunakan Rancangan Acak Kelompok (RAK) dengan pola faktorial $3 \times 3$ dengan 3 ulangan dan dilanjutkan dengan Uji Beda Nyata Jujur (BNJ) taraf 5\% pada hasil uji F yang signifikan. Faktor pertama dosis mikoriza (M) yang terdiri dari 3 taraf yaitu $\mathrm{M}_{0}=0 \mathrm{~g}$ tanaman $^{-1}, \mathrm{M}_{1}=10 \mathrm{~g}$ tanaman $^{-1}, \mathrm{M}_{2}=20 \mathrm{~g}$ tanaman $^{-1}$. Faktor kedua dosis pupuk rock posfat $(\mathrm{P})$ yang terdiri dari 3 taraf yaitu $\mathrm{P}_{1}=150 \mathrm{Kg} \mathrm{ha}^{-1}, \mathrm{P}_{2}=200 \mathrm{Kg} \mathrm{ha}^{-1}, \mathrm{P}_{3}=250 \mathrm{Kg} \mathrm{ha}^{-1}$. Hasil penelitian menunjukkan bahwa perlakuan dosis mikoriza berpengaruh sangat nyata pada berat basah tanaman melon, berat kering tanaman, diameter buah melon, kolonisasi mikoriza akar tanaman melon dan berpengaruh nyata pada tinggi tanaman umur 28 dan 35 HST dan berat buah melon. Perlakuan dosis pupuk rock posfat berpengaruh sangat nyata pada berat basah tanaman melon, diameter buah melon, berat buah melon dan berpengaruh nyata pada tinggi tanaman umur 35 HST dan kolonisasi mikoriza akar tanaman. Terdapat interaksi yang nyata pada parameter berat basah tanaman melon dan berat buah melon.
\end{abstract}

Kata Kunci : Mikoriza, Rock,Posfat, Melon

\begin{abstract}
This research aims to determine the effect of mychorryzae and rock phospate doses on the growth and yield of melon plant. This research was carried out at experimental garden 3, faculty of Agriculture, Syiah Kuala University, Banda Aceh. This research started in Desember 2018 and ended in February 2019. This research used randomized block design factorial $3 \times 3$ with 3 replications and continued with Honestly Significance Difference test (Tukey test) level of $5 \%$ in a significant $F$ test result. The first factor is mychorryzae doses; $\mathrm{M}_{0}=0$ $\mathrm{g}_{\text {plant }}{ }^{-1}, \mathrm{M}_{1}=10 \mathrm{~g} \mathrm{plant}^{-1}, \mathrm{M}_{2}=20 \mathrm{~g}$ plant $^{-1}$. The second factor is rock phospate doses $;=150 \mathrm{Kg} \mathrm{ha}^{-1}, \mathrm{P}_{2}=200$ $\mathrm{Kg} \mathrm{ha}^{-1}, \mathrm{P}_{3}=250 \mathrm{Kg} \mathrm{ha}^{-1}$. The result of research shows that mychorryzae doses treament was very significant in fresh weight, dry weight, melon fruit diameter, mychorryzae colonization in root. It was significant in plant height on 28 and 35 DAT and melon fruit weight. Rock Phospate doses treament was very significant in fresh weight of melon fruit, melon fruit diameter, melon fruit weight. It was significant in plant height $35 \mathrm{HST}$ and mychorryzae colonization in root. There was significant interaction between mychorryzae and rock phospate treatment in fresh weight and fruit weight of melon.
\end{abstract}

Keywords : Mychorryzae, Rock Phospate, Melon

\section{PENDAHULUAN}

Melon adalah salah satu tanaman yang banyak diminati oleh masyarakat karena rasa buah yang manis sehingga memiliki nilai ekonomis. Sehubungan dengan tanaman melon banyak diminati oleh masyarakat maka sangat berpeluang untuk dibudidayakan secara baik dan benar agar menghasilkan hasil produksi yang maksimal. (Arfah et al., 2016)

Badan Pusat Statistik Indonesia (2016), pada tahun 2014 produksi melon sebesar 150.374 ton, mengalami penurunan produksi menjadi 137.557 ton pada tahun 2015 dan penurunan kembali terjadi pada tahun 2016 menjadi 117.341 ton. Pertumbuhan melon sangat dipengaruhi oleh ketersediaan unsur hara. Hara yang dibutuhkan oleh tanaman melon diantaranya $\mathrm{N}, \mathrm{P}$ dan $\mathrm{K}$, namun pupuk $\mathrm{P}$ merupakan pupuk yang ketersediannya 
rendah.Alterrnatif yang dapat digunakan untuk mengikat unsur $\mathrm{K}$ dan unsur $\mathrm{P}$ yang rendah dalam tanah adalah dengan penggunaan mikoriza. Mikoriza merupakan suatu gambaran hubungan dari simbiosis mutualisme antara fungi dengan perakaran tumbuhan tingkat tinggi. Fungi tersebut menginfeksi tanaman, namun tidak bersifat parasit, akan tetapi dapat menambah asupan nutrisi untuk tanaman inangnya, diantaranya unsur $\mathrm{P}, \mathrm{Ca}, \mathrm{N}, \mathrm{Cu}, \mathrm{Mn}, \mathrm{K}$ dan $\mathrm{Mg}$ (Hardiatmi, 2008).

Pemanfaatan fungi mikoriza arbuskular memberikan hal positif bagi tanaman dalam penyerapan hara $\mathrm{P}$ (fosfor) pada kondisi $\mathrm{P}$ rendah, meningkatkan pertumbuhan tanaman, serta meningkatkan ketahanan tanaman terhadap penyakit dan cekaman, seperti kekeringan dan salinitas (Jeffries et al., 2003; Porras-Soriano et al., 2009; Cruz et al., 2014). Maka melon dapat bersimbiosis dengan FMA saat pertumbuhannya (Srivastava et al., 2012). Salah satu peran fungi mikoriza arbuskular yaitu mampu menghadapi cekaman kekeringan pada tanaman melon dan mereduksi fungi patogen, seperti Fusarium (Huang et al., 2011; Martínez-Medina et al., 2011).

Dalam upaya memenuhi kebutuhan tanaman akan unsur $\mathrm{P}$ yang bertujuan untuk meningkatkan pertumbuhan dan produksi tanaman melon, selain menggunakan mikoriza juga dapat dilakukan dengan menggunakan pupuk rock posfat sebagai sumber unsur P. Rock posfat merupakan sumber pupuk $\mathrm{P}$ anorganik yang efektif dan murah.

\section{METODE PENELITIAN}

\section{Tempat dan Waktu Penelitian}

Penelitian dilaksanakan di Kebun Percobaan 3 Fakultas Pertanian Universitas Syiah Kuala Banda Aceh. Penelitian ini akan dilaksanakan pada Desember 2018 sampai Februari 2019.

Alat dan Bahan

Alat yang digunakan yaitu cangkul, gembor, meteran, ember, jangka sorong, timbangan analitik, amplop dan gunting. Bahan yang digunakan adalah benih melon varietas AMANTA F1 digunakan sebanyak 250 benih, mikoriza jenis Glomus mossae, sebanyak 2.160 g, pupuk Rock posfat $1.296 \mathrm{~g}$, pupuk urea $2.916 \mathrm{~g}$, pupuk $\mathrm{KCl} 4.644 \mathrm{~g}$, ajir ukuran 2 meter, pupuk kandang $195 \mathrm{~kg}$ dan polybag ukuran 8 x $9 \mathrm{~cm}$ untuk pembibitan dan tali rafia

\section{Analisis Data}

Penelitian menggunakan Rancangan Acak Kelompok (RAK) dengan pola faktorial 3x3 dengan 3 ulangan. Faktor pertama adalah dosis mikoriza Glomus mossae yang terdiri dari 3 taraf yaitu $0 \mathrm{~g}_{\text {tanaman }}^{-1}, 10 \mathrm{~g}$ tanaman $^{-1}, 20 \mathrm{~g}_{\text {tanaman }}{ }^{-1}$. Faktor kedua adalah dosis rock posfat yang terdiri dari 3 taraf yaitu $150 \mathrm{~kg} \mathrm{ha}^{-1}, 200 \mathrm{~kg} \mathrm{ha}^{-1}$ dan $250 \mathrm{~kg} \mathrm{ha}^{-1}$.

\section{Pelaksanaan Penelitian}

\section{Persiapan Media Pembibitan}

Tanah dan pupuk kandang dicampur dengan perbandingan 2:1 yaang sebelumnya sudah diayak terlebih dahulu. Kemudian campuran media dimasukkan ke dalam polybag ukuran $8 \mathrm{x}$ 9 cm sebanyak 250 . 


\section{Pembibitan Benih Melon}

Benih melon AMANTA F1 direndam di dalam air yang berisi larutan pestisida dithane selama 5 menit kemudian diletakan pada handuk yang sudah di diberi air dan disimpan selama 24 jam. Benih melon yang digunakan disemai pada polybag yang disiapkan.

\section{Persiapan Lahan}

Bedengan dibuat dengan panjang $2 \mathrm{~m} \times 1,2 \mathrm{~m}$. Saluran air antar bedengan dibuat dengan lebar $50 \mathrm{~cm}$ dan kedalaman $50 \mathrm{~cm}$. Jarak lubang tanam setiap tanaman yaitu $50 \mathrm{x} 80 \mathrm{~cm}$.

\section{Pemupukan}

Pupuk kandang sebagai pupuk dasar yang diberikan seminggu sebelum pindah tanam sebanyak 7,2 g bedeng $^{-1}$. Pupuk Urea dan $\mathrm{KCl}$ digunakan sebagai pupuk dasar yang diberikan pada saat seminggu sebelum pindah tanam dan pada hari ke 20 setelah pindah tanam sebanyak $108 \mathrm{~g}$ bedeng $^{-1}$ untuk Urea dan $172 \mathrm{~g}$ bedeng $^{-1}$ untuk KCl. Pupuk rock posfat sebagai pupuk perlakuan dalam penelitian ini diberikan seminggu sebelum pemindahan bibit tanaman ke lahan, dengan dosis sesuai dengan perlakuan yaitu 150, 200, dan $250 \mathrm{~kg} \mathrm{ha}^{-1}$ setelah dikonversi menjadi 36,48,60 $\mathrm{g}$ bedeng $^{-1}$.

\section{Pemasangan Ajir}

Ajir dipasang disamping tanaman melon dengan tinggi ajir 2 meter.

\section{Penanaman dan Pemberian Mikoriza}

Penanaman bibit melon dilakukan saat bibit melon berumur 14 hari setelah semai. Selanjutnya pemberian mikoriza glomus mossae dilakukan bersamaan pada saat bibit dipindah tanam ke lapangan, yaitu diberikan pada lubang tanam sesuai dengan perlakuan yaitu 0, 10 dan $20 \mathrm{~g}$.

\section{Pemeliharaan Tanaman}

Pemeliharaan tanaman terdiri dari penyiraman, penyulaman, pengajiran, pengendalian hama dan penyakit tanaman dan pemangkasan. Pemangkasan d tunas disetiap ketiak daun yang dilakukan mulai dari ruas ke -1 sampai ruas ke -9 , namun buah yang dipelihara diambil pada ruas ke-10 dan ke-13, yang sudah berumur 40 hari setelah pindah tanam

\section{Panen}

Pemanenan dilakukan ketika buah berumur 70 HST. Kriteria pemanenan yaitu adanya keretakan pada kulit dan sudah berwarna kuning serta mengeluarkan aroma harum.

\section{Parameter Pengamatan}

Tinggi Tanaman (cm)

Pengukuran tinggi tanaman dilakukan pada saat tanaman berumur 7, 14, 21, 28 dan 35 Hari Setelah Tanam (HST). Pengukuran dilakukan dari pangkal batang hingga ujung titik tumbuh tanaman menggunakan meteran.

\section{Diameter Pangkal Batang`(mm)}

Pengukuran diameter pangkal batang dilakukan pada saat tanaman berumur 7, 14, 21, 28 dan 35 HST. Pengukuran dilakukan pada batang yang berada $2 \mathrm{~cm}$ diatas permukaan media tanam dengan menggunakan jangka sorong. 


\section{Berat Basah Berangkasan Tanaman Melon}

Pengukuran berat basah dilakukan menggunakan neraca analitik digital. Berat basah total adalah hasil penjumlahan antara berat basah pucuk dengan berat basah akar pengukuran berat basah setelah buah dipanen.

\section{Berat Kering Berangkasan Tanaman Melon}

Pengukuran berat kering total dilakukan setelah bagian tanaman dikeringkan dalam oven (suhu $75^{\circ} \mathrm{C}$ ) selama 24 jam. Bagian tanaman tersebut kemudian ditimbang beratnya menggunakan neraca analitik digital. Berat kering total adalah penjumlahan antara berat kering pucuk dengan berat kering akar.

\section{Diameter Buah Melon (cm)}

Pengukuran diameter buah melon dilakukan pada panen (70 HST), yaitu dengan menggunakan meteran yang dilingkari pada buah melon.Yang kemudian akan di konversi denga rumus $: d=\frac{\text { Keliling Buah }}{3,14}$

\section{Bobot Buah Melon (g)}

Buah yang sudah dipanen ditimbang berat buah melon menggunakan timbangan.

\section{Analisis Kolonisasi mikoriza Glomus mossae pada Akar Tanaman Melon}

Struktur infeksi cendawan diamati pada umur 45 HST, pewarnaan akar menggunakan pewarna biru trypan. Pertumbuhan cendawan dan persentase kolonisasi di dalam akar dilakukan dengan menggunakan metode slide.

Potongan akar dengan panjang $1 \mathrm{~cm}$ sebanyak 5 potong diambil secara acak dan disusun pada kaca preparat, kemudian diamati di bawah mikroskop pada setiap bidang pandang. Selanjutnya, persentase kolonisasi akar dihitung dengan menggunakan rumus:

$$
\% \text { Kolonisasi akar }=\frac{\text { Jumlah akar terkolonisasi }}{\text { Jumlah akar yang diamati }} \times 100 \%
$$

\section{HASIL DAN PEMBAHASAN}

\section{Pengaruh Dosis Mikoriza terhadap Pertumbuhan dan Hasil Tanaman Melon}

Hasil Uji $\mathrm{F}$ mengemukakan perlakuan dosis mikoriza berpengaruh sangat nyata terhadap berat basah berangkasan tanaman melon, berat kering berangkasan tanaman melon, diameter buah melon dan kolonisasi mokiriza Glomus mossae akar tanaman melon, selanjutnya berpengaruh nyata pada tinggi tanaman 28, 35 HST dan berat buah melon. Berikut ini adalah rata-rata pengaruh dosis mikoriza pterhadap pertumbuhan dan hasil tanaman melon yang dapat dilihat pada Tabel 1. 
Tabel 1. Rata-Rata Pengaruh Dosis Mikoriza terhadap Parameter Pertumbuhan dan Hasil Tanaman Melon.

\begin{tabular}{|c|c|c|c|c|c|}
\hline \multirow{2}{*}{\multicolumn{2}{|c|}{ Parameter yang diamati }} & \multicolumn{3}{|c|}{ Dosis Mikoriza } & \multirow{2}{*}{$\mathrm{BNJ}_{0,05}$} \\
\hline & & \multirow{2}{*}{$\frac{0 \mathrm{~g} \mathrm{tan}^{-1}}{17,83}$} & \multirow{2}{*}{$\frac{10 \mathrm{~g} \mathrm{tan}^{-1}}{17,33}$} & \multirow{2}{*}{$\begin{array}{c}20 \mathrm{~g} \mathrm{tan}^{-1} \\
17,78\end{array}$} & \\
\hline Tinggi Tanaman & 7 HST (cm) & & & & \\
\hline & $14 \operatorname{HST}(\mathrm{cm})$ & 33,53 & 31,86 & 31,42 & \\
\hline & $21 \operatorname{HST}(\mathrm{cm})$ & 50,75 & 54,32 & 53,10 & \\
\hline & $28 \operatorname{HST}(\mathrm{cm})$ & 69,78 & $80,39 \mathrm{ab}$ & 89,41 b & 18,06 \\
\hline & $35 \operatorname{HST}(\mathrm{cm})$ & 129,53 & $139,43 \mathrm{ab}$ & $150,06 \mathrm{~b}$ & 19,10 \\
\hline Diameter Pangka & g 7 HST(cm) & 2,86 & 2,87 & 2,83 & \\
\hline & $14 \operatorname{HST}(\mathrm{cm})$ & 4,18 & 4,21 & 4,11 & \\
\hline & $21 \mathrm{HST}(\mathrm{cm})$ & 5,06 & 5,18 & 5,11 & \\
\hline & $28 \operatorname{HST}(\mathrm{cm})$ & 6,09 & 6,24 & 6,52 & \\
\hline & $35 \operatorname{HST}(\mathrm{cm})$ & 7,27 & 7,35 & 7,56 & \\
\hline \multicolumn{6}{|c|}{ Berat Basah Berangkasan Tanaman } \\
\hline \multicolumn{6}{|c|}{ Berat Kering Berangkasan Tanaman } \\
\hline Melon (g) & & 64,89 & 54,97 a & 89,49 b & 14,30 \\
\hline Diameter Buah m & $\mathrm{nm})$ & 11,69 & $13,27 \quad b$ & $15,13 \mathrm{c}$ & 0,99 \\
\hline \multicolumn{6}{|c|}{ Kolonisasi FMA Akar Tanaman } \\
\hline Melon $(\%)$ & & 1,40 & $44,34 \mathrm{~b}$ & $57,17 \quad \mathrm{c}$ & 3,87 \\
\hline
\end{tabular}

Keterangan : Angka yang diikuti oleh huruf yang sama pada baris yang sama menunjukkan berbeda tidak nyata pada uji BNJ $(\alpha=0,05)$.

Pada Tabel 1 mengemukakan bahwa tinggi tanaman melon akibat perlakuan beberapa dosis mikoriza pada umur 28 dan 35 HST nilai tertinggi dijumpai pada dosis mikoriza $20 \mathrm{~g} \mathrm{tan}^{-}$ ${ }^{1}$ yaitu $89,41 \mathrm{~cm}$ dan $150,06 \mathrm{~cm}$. Selanjutnya pada berat basah dan berat kering melon nilai tertinggi dijumpai pada dosis mikoriza $20 \mathrm{~g} \mathrm{tan}^{-1}$ yaitu 288,48 g dan 89,49 g. Pada diameter buah melon dan berat buah melon nilai tertinggi dijumpai pada dosis mikoriza $20 \mathrm{~g} \mathrm{tan}^{-1}$ yaitu $15,13 \mathrm{~mm}$ dan $1,98 \mathrm{~kg}$. Selanjutnya pada parameter kolonisasi mikoriza Glomus mossae akar tanaman melon nilai tertinggi dijumpai pada dosis mikoriza $20 \mathrm{~g} \mathrm{tan}^{-1}$ yaitu 57,17\%.

Hasil penelitian mengemukakan bahwa pemberian mikoriza berpengaruh nyata terhadap tinggi tanaman umur 28 dan 35 HST, hal ini dikarenakan mikoriza diketahui dapat meningkatkan tinggi tanaman, panjang akar, diameter batang, bobot basah dan bobot kering tajuk, bobot basah dan bobot kering akar melon (Huang et al (2011). Hifa eksternal jamur mikoriza Glomus mossae dapat membantu penyerapan air dan unsur-unsur hara yang digunakan dalam proses metabolisme didalam tubuh tanaman sehingga dapat memacu pertumbuhan tinggi tanaman (Utomo, 2009).

Infeksi mikoriza diketahui dapat meningkatkan pertumbuhan tanaman termasuk jumlah daun, tinggi tanaman dan luas daun karena tanaman bermikoriza dapat menyerap unsur hara makro dalam jumlah beberapa kali lebih besar dibanding tanpa mikoriza, khususnya pada tanah yang miskin unsur hara seperti tanah ultisol pada percobaan ini, terutama P (Hodiah, 2008). Widi et al., (2010) menyatakan bahwa pemberian mikoriza dapat meningkatkan bobot buah dimana ukuran buah yang semakin besar sehingga jumlah benih semakin banyak yang nantinya 
akan berpengaruh terhadap bobot benih pada buah dan bobot benih yang dihasilkan lebih bermutu dan berbobot.

\section{Pengaruh Pupuk Rock posfat terhadap Pertumbuhan dan Hasil Tanaman Melon}

Berikut ini adalah rata-rata pengaruh dosis mikoriza pterhadap pertumbuhan dan hasil tanaman melon yang dapat dilihat pada Tabel 2 .

Tabel 2. Rata-Rata Pengaruh Pupuk Rock posfat Terhadap Parameter Pertumbuhan dan Hasil Tanaman Melon.

\begin{tabular}{|c|c|c|c|c|c|}
\hline \multirow{2}{*}{\multicolumn{2}{|c|}{ Parameter yang diamati }} & \multicolumn{3}{|c|}{ Pupuk Rock posfat } & \multirow{2}{*}{$\mathrm{BNJ}_{0,05}$} \\
\hline & & $150 \mathrm{~kg} \mathrm{ha}^{-1}$ & $200 \mathrm{~kg} \mathrm{ha}^{-1}$ & $250 \mathrm{~kg} \mathrm{ha}^{-1}$ & \\
\hline \multirow[t]{5}{*}{ Tinggi Tanaman } & 7 HST $(\mathrm{cm})$ & 17,94 & 17,22 & 17,78 & \\
\hline & $14 \mathrm{HST}(\mathrm{cm})$ & 32,58 & 30,89 & 33,02 & \\
\hline & $21 \operatorname{HST}(\mathrm{cm})$ & 52,12 & 51,51 & 54,54 & \\
\hline & $28 \operatorname{HST}(\mathrm{cm})$ & 80,80 & 81,66 & 77,14 & \\
\hline & $35 \operatorname{HST}(\mathrm{cm})$ & $127,02 \mathrm{a}$ & $149,72 \mathrm{~b}$ & $142,27 \mathrm{ab}$ & 19,10 \\
\hline \multicolumn{2}{|c|}{ Diameter Pangkal Batang 7 HST $(\mathrm{cm})$} & 2,80 & 2,94 & 2,81 & \\
\hline & $14 \operatorname{HST}(\mathrm{cm})$ & 4,13 & 4,24 & 4,12 & \\
\hline & $21 \mathrm{HST}(\mathrm{cm})$ & 5,04 & 5,11 & 5,19 & \\
\hline & $28 \operatorname{HST}(\mathrm{cm})$ & 5,93 & 6,36 & 6,57 & \\
\hline & 35 HST $(\mathrm{cm})$ & 7,28 & 7,38 & 7,51 & \\
\hline \multicolumn{6}{|c|}{ Berat Basah Berangkasan Tanaman } \\
\hline \multicolumn{6}{|c|}{ Berat Kering Berangkasan Tanaman } \\
\hline Melon (g) & & 71,66 & 66,90 & 70,79 & \\
\hline Diameter Buah m & $\mathrm{nm})$ & 12,72 a & $13,20 \mathrm{ab}$ & $14,16 \quad b$ & 0,99 \\
\hline Berat Buah Melo & & $1,46 \quad \mathrm{a}$ & $1,49 a$ & 1,70 & 0,20 \\
\hline \multicolumn{2}{|c|}{$\begin{array}{l}\text { Kolonisasi FMA Akar Tanaman Melon } \\
(\%)\end{array}$} & 31,80 a & $35,27 \mathrm{ab}$ & $35,84 \quad b$ & 3,87 \\
\hline
\end{tabular}

Keterangan : Angka yang diikuti oleh huruf yang sama pada baris yang sama menunjukkan berbeda tidak nyata pada uji BNJ $(\alpha=0,05)$.

Perlakuan pupuk rock posfat berpengaruh sangat nyata terhadap berat basah tanaman melon, diameter buah melon dan berat buah melon, selanjutnya berpengaruh nyata terhadap tinggi tanaman 35 HST dan kolonisasi mikoriza Glomus mossae akar tanaman melon, serta berpengaruh tidak nyata terhadap parameter lainnya.

Pada Tabel 2 menunjukkan bahwa tinggi tanaman melon akibat perlakuan beberapa pupuk rock posfat pada umur $35 \mathrm{HST}$ nilai tertinggi dijumpai pada pupuk rock posfat $200 \mathrm{~kg}$ $\mathrm{ha}^{-1}$ yaitu $149,72 \mathrm{~cm}$. Selanjutnya pada parameter berat basah tanaman melon nilai tertinggi dijumpai pada pupuk rock posfat $250 \mathrm{~kg} \mathrm{ha}^{-1}$ yaitu $277,31 \mathrm{~g}$. Pada parameter diameter buah dan kolonisasi mikoriza Glomus mossae akar tanaman melon nilai terbaik dijumpai pada pupuk rock posfat $250 \mathrm{~kg} \mathrm{ha}^{-1}$ yaitu $14,16 \mathrm{~mm}$ dan $35,84 \%$. Selanjutnya pada parameter berat buah nilai tertinggi dijumpai pada pupuk rock posfat $250 \mathrm{~kg} \mathrm{ha}^{-1}$ yaitu $1,70 \mathrm{~kg}$.

Hasil penelitian mengemukakan bahwa rock fosfat menunjukkan pengaruh nyata pada parameter tinggi tanaman 35 HST hal ini diduga karena fosfat merupakan unsur hara 
makro yang penting dalam aktivitas metabolisme tanaman sebagai penyusun ATP yang berperan dalam transfer energi; NADP dalam proses fotosintesis; membrane sel dan organ dalam sel karena bagian dari fospolipid; pembentukan asam nukleat yang akan menjadi bahan pembentukan DNA dan RNA. Namun pengaruhnya secara agronomis lebih kepada merangsang perkembangan akar, mengaktifkan peranakan, merangsang pembentukan bunga dan pematangan, berperan aktif dalam perkembangan biji dan memperbaiki kualitas biji (Kristina, 2016).

Hasil penelitian menunjukkan bahwa Rock posfat memiliki pengaruh sangat nyata pada parameter diameter buah dengan perlakuan terbaik ditunjukkan pada $250 \mathrm{~kg} \mathrm{ha}^{-1}$, hal ini diduga karena unsur $\mathrm{P}$ yang terkandung pada pupuk rock posfat bermanfaat pada fase generatf tanaman diantaranya diameter buah. Pemberian rock phosphate membantu mencukupi kebutuhan $\mathrm{P}$ untuk pertumbuhan tanaman melon. Hal ini sejalan dengan penelitian Rengganis (2014) bahwa pemberian pupuk rock fosfat dengan dosis $150 \mathrm{~kg} \mathrm{ha}^{-1}$ mampu meningkatkan bobot basah dan bobot kering tanaman kedelai.

\section{Pengaruh Interaksi antara Dosis Mikoriza dan Pupuk Rock posfat terhadap Pertumbuhan dan Hasil Tanaman Melon}

Hasil uji $\mathrm{F}$ pada analisis ragam menunjukkan bahwa terdapat interaksi yang nyata antara perlakuan pupuk rock posfat dengan mikoriza pada parameter berat basah tanaman melon dan berat buah tanaman melon. Tabel interaksi dapat dilihat pada tabel 3 dan 4 .

Tabel 3. Rata-rata Berat Basah Tanaman Melon akibat Interaksi Berbagai Dosis Mikoriza dan Pupuk Rock posfat

\begin{tabular}{cccc}
\hline \multirow{2}{*}{$\begin{array}{c}\text { Dosis } \\
\text { Mikoriza }(\mathrm{g} \\
\left.\operatorname{tanaman}^{-1}\right)\end{array}$} & $\mathrm{P}_{1}(150)$ & $\mathrm{P}_{2}(200)$ & $\mathrm{P}_{3}(250)$ \\
\hline $\mathrm{M}_{0}(0)$ & $198,01 \mathrm{Aa}$ & $231,22 \mathrm{Aa}$ & $222,83 \mathrm{Ab}$ \\
$\mathrm{M}_{1}(10)$ & $223,97 \mathrm{Aa}$ & $227,89 \mathrm{Aa}$ & $268,02 \mathrm{Bb}$ \\
$\mathrm{M}_{2}(20)$ & $256,27 \mathrm{Aa}$ & $268,12 \mathrm{Aa}$ & $341,05 \mathrm{Cb}$ \\
\hline BNJ 0,05 & & 41,90 &
\end{tabular}

Keterangan: Angka-angka yang diikuti oleh huruf yang sama (huruf kapital notasi pada kolom, huruf kecil notasi pada baris) menunjukan berbeda tidak nyata pada uji $\mathrm{BNJ}(\alpha=0,05)$

Penambahan dosis mikoriza tidak menunjukkan interaksi yang berpengaruh nyata pada perlakuan pupuk Rock Pospat $150 \mathrm{~kg} / \mathrm{ha}^{-1}$ dan $200 \mathrm{~kg} / \mathrm{ha}^{-1}$. Hal ini menunjukkan bahwa penambahan dosis mikoriza baru berinteraksi dengan pupuk rock pospat jika dosis pupuk rock pospat yang diberikan adalah $250 \mathrm{~kg} / \mathrm{ha}^{-1}$. Pada dosis rock pospat tersebut semakin tinggi dosis mikoriza yang ditambahkan maka semakin tinggi berat basah tanaman yang dihasilkan. Hal ini diduga karena mikoriza mampu membuat ketersediaan pupuk rock pospat agar dapat terserap dengan lebih baik oleh tanaman. 
Tabel 4. Rata-rata Berat Buah Melon akibat Interaksi Berbagai Dosis Mikoriza dan Pupuk Rock posfat

\begin{tabular}{cccc}
\hline \multirow{2}{*}{$\begin{array}{c}\text { Dosis } \\
\text { Mikoriza }(\mathrm{g} \\
\left.\operatorname{tanaman}^{-1}\right)\end{array}$} & $\mathrm{P}_{1}(150)$ & $\mathrm{P}_{2}(200)$ & $\mathrm{P}_{3}(250)$ \\
\cline { 2 - 4 } $\mathrm{M}_{0}(0)$ & $2.101 \mathrm{Ab}$ & $2.426 \mathrm{Ac}$ & $1.327 \mathrm{Aa}$ \\
$\mathrm{M}_{1}(10)$ & $2.253 \mathrm{Aa}$ & $3.280 \mathrm{Bb}$ & $2.434 \mathrm{Ba}$ \\
$\mathrm{M}_{2}(20)$ & $3.550 \mathrm{Ba}$ & $3.472 \mathrm{Ba}$ & $3.887 \mathrm{Cb}$ \\
\hline BNJ 0,05 & & 247,30 & \\
\hline
\end{tabular}

Keterangan: Angka-angka yang diikuti oleh huruf yang sama (huruf kapital notasi pada kolom, huruf kecil notasi pada baris) menunjukan berbeda tidak nyata pada uji $\mathrm{BNJ}(\alpha=0,05)$

Kombinasi terbaik pada parameter berat basah dan berat buah tanaman melon dapat dijumpai pada kombinasi perlakuan dosis mikoriza $20 \mathrm{~g} \mathrm{tan}^{-1}$ dan pupuk rock posfat $250 \mathrm{~kg} \mathrm{ha}$ ${ }^{1}\left(\mathrm{M}_{2} \mathrm{P}_{3}\right)$.

\section{KESIMPULAN}

\section{KESIMPULAN DAN SARAN}

Pertumbuhan dan hasil tanaman melon yang lebih baik terdapat pada dosis mikoriza $20 \mathrm{~g}$ tanaman $^{-1}$. Sedangkan pertumbuhan dan hasil tanaman melon yang lebih baik pada perlakuan rock posfat terdapat pada dosis rock fosfat $250 \mathrm{~kg} \mathrm{ha}^{-1}$. Terdapat interaksi yang nyata antara dosis mikoriza dan dosis rock fosfat terhadap berat berangkasan basah dan berat buah melon. Berat berangkasan basah dan berat buah yang lebih baik terdapat pada kombinasi perlakuan dosis mikoriza $20 \mathrm{~g}_{\text {tanaman }}{ }^{-1}$ dengan dosis rock fosfat $250 \mathrm{~kg} \mathrm{ha}^{-1}$.

\section{SARAN}

Perlu dilakukan penelitian lebih lanjut menggunakan mikoriza dengan dikombinasikan menggunakan pupuk organic cair.

\section{DAFTAR PUSTAKA}

Arafah, C. Z., F. Harun dan M. Rahmawati. 2016. Pengaruh media tanam dan konsentrasi zat pengatur tumbuh dekamon pada pertumbuhan dan hasil tanaman melon (Cucumis melo L.) Jurnal Kawista. 1(1): 10-14.

Badan Pusat Statistik (BPS) 2016. Statistik Tanaman Sayuran dan Buah-buahan Semusim tahun 2016. Badan pusat Statistik Indonesia. Jakarta.

Cruz, A. F., W. R. de Oliveira-soares and L. E. B. Blum. 2014. Impact of the arbuscular mychorhizal fungal (Glomus facciculatum) colonization in re-cycling and open system. African Journal of Biotechnology. 2(1): 1-5.

Hardiatmi, J. M. S. 2008. Pemanfaatan jasad renik mikoriza untuk memacu pertumbuhan tanaman hutan. Jurnal Inovasi Pertanian. 7(1): 1-10.

Hodiah. 2008. Hasil jagung yang diinokulasi cendawan mikoriza arbuskula dan diberi fraksi humat jeram padi pada tanah ultisol. Jurnal Agrivor. 7(2): 141-148. 
Huang, Z., Z. Zou., C. He., Z. He., Z. Zhang and J. Li. 2011. Physiological and photosynthetic responses of melon (Cucumis melo L.) seedlings ti three Glomus species under water deficit. Plant and Soil. 339: 391-399.

Jeffries, P., S. Gianinazzi., S. Perotto., K. Turnau., and J. Barea. 2003. The contribution of arbuscular michorrizal fungi in sustainable maintenance of plant health and soil fertility. Biology and Fertility of Soil. 37: 1-16.

Kristina, N., dan M. Harianti. 2016. Ekspresi kubis bunga hoggar pada andisol gunung singgalang versus kubis local terhadap pemberian pupuk organic cair dan batuan fosfat. Jurnal BioETI. 52-57.

Poras-Soriano, A., M.L. Soriano-Martin, A. Porras-Piedra, R. Azcon. 2009. Arbuscullar micorrhizal fungi increased growth, nutrient uptake and tolerance to salinity in olive tress under nursery condition. Plant Physiology. 166: 1350-1359.

Rengganis, R.D., Y. Hasanah dan N. Rahmawati. 2014. Peran fungi mikoriza arbuskular dan pupuk rock fosfat terhadap pertumbuhan dan produksi kedelai. Skripsi Program Agroekoteknologi, Fakultas Pertanian. USU.

Srivastava, N. K., D. K. Srivastaka., PP. Singh. 2012. A preliminary survey of the vesicular arbuscular mycorrhizal status of vegetable and fruit yielding plants in Eastern U.P. Indian Journal of Land and Sciences. 1(2); 79-82.

Utomo, B. 2009. Pemanfatan beberapa bioaktivator terhadap laju dekomposisi tanah gambut dan pertumbuhan Gmelina arborea Roxb. Jurnal LIPI 